\title{
DESAIN DAN IMPLEMENTASI SISTEM PEMBELAJARAN ELEKTRONIK BERBASIS WEB PADA RUMUS MATEMATIKA DASAR MENGGUNAKAN FRAMEWORK LARA VEL
}

\author{
Rizky Parlika ${ }^{1}$, Agung Syaiful Umar ${ }^{2}$, Roby Sirojul A ${ }^{3}$, Evendi ${ }^{4}$, M Andhik Pratama $^{5}$ \\ Fakultas Ilmu Komputer Universitas Pembangunan Nasional \\ "Veteran" Jawa Timur \\ Jl. Rungkut Madya No.1, Gn. Anyar, Kec. Gn. Anyar, Kota \\ SBY, Jawa Timur 60294 \\ E-mail : rizkyparlika.if@upnjatim.ac.id ${ }^{1}$, agungsyaiful03@gmail.com², \\ roby.sirojul@gmail.com ${ }^{3}$, evendischool@gmail.com ${ }^{4}$, andhikpratama0@gmail.com ${ }^{5}$
}

Penelitian ini bertujuan untuk meningkatkan kualitas pendidikan dengan prinsip utama pembelajaran menggunakan sistem elektronik atau komputer sehingga mampu mendukung pembelajaran. Metode pembelajaran dalam dunia pendidikan semakin berkembang dengan adanya teknologi informasi. Pembelajaran elektronik atau e-learning adalah salah satu metode pembelajaran yang muncul karena perkembangan teknologi informasi. Aplikasi e-learning akan dibangun menggunakan Framework Laravel. Laravel dipilih karena memiliki konsep pemrograman berbasis Model View Controller (MVC). Pemrograman MVC adalah metode pemrograman dengan cara memisahkan antara data dari tampilan serta cara bagaimana memprosesnya. Teknologi pembuatan website yang sudah sangat berkembang ini diimbangi dengan perkembangan internet sehingga berbagai media sudah berbasis online seperti situs media pembelajaran, saat ini sudah cukup banyak situs media pembelajaran di internet, materi yang berkualitas dan tenaga pengajar berpengalaman membuat kita harus mengeluarkan biaya yang cukup mahal. Oleh karena itu e-learning media pembelajaran dengan materi gratis tentunya sangat membantu masyrakat yang ingin mengembangkan pengetahuannya. Penelitian ini menghasilkan sebuah website e-learning media pembelajaran yang dibuat menggunakan framework Laravel dengan fitur seperti menghitung langsung.

Kata Kunci : E-Learning , Laravel, $M V C$

This research aims to improve the quality of education with the main principles of learning using electronic or computer systems so that they can support learning. Learning methods in the world of education increase rapidly with the existence of information technology. Electronic learning or e-learning is one of the learning methods that emerged due to the development of information technology. The e-learning application will be built using the Laravel Framework. Laravel is chosen because it has a concept of programming based on the Model View Controller (MVC). $M V C$ programming is a programming method by separating data from views and how to process it. This highly developed website creation technology is balanced with the development of the internet so that various media have been online based such as learning media site, currently there are enough learning media sites on the internet, quality material and experienced teaching staff makes us have to pay quite expensive fees. Therefore e-learning learning media with free material is certainly very helpful for people who want to develop their knowledge. This research results an e-learning website for learning media created using the Laravel framework with features such as direct counting.

Keywords : E-Learning, Laravel, MVC 
JURNAL NUANSA INFORMATIKA

Volume 14 Nomor 1, Januari 2020

\section{PENDAHULUAN}

Perkembangan global saat ini selalu diikuti dengan perkembang teknologi yang sangat pesat khususnya pada teknologi informasi, sehingga mengharuskan pendidikan Indonesia turut berkembang dengan memaksimalkan teknologi informasi yang ada seperti web dengan tujuan mengembangkan kemampuan berpikir para siswa. Sama seperti bidang lainnya, teknologi informasi juga erat hubungannya dengan pendidikan, walaupun pada dasarnya teknologi memberikan pengaruh positif dan negatif.

Pengaruh positif dari perkembangan teknologi informasi ini adalah semakin mudahnya masyarakat dalam bertukar informasi serta mengakses kebutuhan informasi melalui media social ataupun lainnya yang bisa dinikmati dari dan seluruh dunia. Sedangkan pengaruh negatifnya juga sama besarnya yaitu penyalahgunaan teknologi yang menyalahi aturan, norma, nilai, dan moral kehidupan di masyarakat. Menyikapi keadaan ini maka peran pendidikan dalam memberikan pengaruh positif dalam teknologi informasi sangat penting khususnya dalam menyelesaikan pemasalahan pelajaran-pelajaran yang dianggap sulit oleh siswa contohnya matematika.

Pendidikan adalah segala upaya yang terencana untuk mewujudkan suasana belajar dan proses pembelajaran agar peserta didik secara aktif mengembangkan potensi dirinya untuk memiliki kekuatan spiritual keagamaan, pengendalian diri, kepribadian, kecerdasan, akhlak mulia, serta keterampilan yang diperlukan dirinya dan masyarakat. Dengan kata lain dunia pendidikan adalah proses dimana mempersiapkan sumber daya manuasia yang berkualitas dalam berbagai bidang.(Krisdiawan, 2015).

Pembelajaran matematika di Sekolah Dasar (SD) merupakan salah satu pokok ajaran yang harus disampaikan kepada siswa karena pelajaran matematika
p-ISSN : 1858-3911, e-ISSN : 2614-5405

https://journal.uniku.ac.id/index.php/ilkom

SD merupkan dasar pembelajaran yang akan digunakan pada jenjang SMP, SMA, maupun perguruan tinggi.

Menurut Ibrahim dalam (Ningrum, 2017)“

Matematika disebut ilmu deduktif, sebab dalam matematika tidak menerima generalisasi yang berdasarkan pada observasi, eksperimen, coba-coba (induktif) seperti halnya ilmu pengetahuan alam dan ilmu-ilmu pengetahuan umumnya. Kebenaran generalisasi matematika harus dapat dibuktikan secara deduktif ". Dalam jurnal (Hasratuddin, 2018) mengatakan bahwa matematika adalah suatu cara untuk pemecahan masalah manusia menggunakan informasi, bentuk dan ukuran serta pengetahuan tentang menghitung. Pembelajaran matematika juga diharapkan mampu memberikan kemampuan khusus serta diharapkan memiliki kemampuan mengenal, menjelaskan hubungan, serta memecahkan masalah dengan menggunakan pemikiran yang logis dalam konsep bilangan, geometri dan pengukuran.

Pada kenyataannya siswa kurang menguasai matematika dan kurang memperhatikan penjelasan guru melalui media belajar. sebagaimana yang diungkapkan oleh Wahyudin (dalam P. T. Aditya, 2018) bahwa matematika merupakan mata pelajaran yang sulit untuk diajarkan maupun dipelajari. Jadi tidak salah jika peserta didik tidak tertarik dan tidak mampu belajar matematika dengan baik, sehingga belajar matematika menjadi sulit. Sehingga penggunaan media pembelajaran yang modern sangat diperlukan untuk meningkatkan keinginan belajar siswa. Hamalik ( dalam Hartono, 2013) mengemukakan bahwa pemakaian media pembelajaran dalam proses belajar mengajar dapat membangkitkan keinginan dan motivasi belajar karena adanya rangsangan kegiatan belajar yang mempengaruhi psikologis siswa. penerapan teknologi dalam pendidikan 
JURNAL NUANSA INFORMATIKA

Volume 14 Nomor 1, Januari 2020

sangat penting contohnya dalam penerapan web untuk media pembelajan. Media pembelajaran berbasis web dirasa sangat relevan mengingat bahwa setiap siswa menginginkan pembelajaran yang efektif, efisien, sekaligus menyenangkan sesuai dengan perkembangan IPTEKS (Rubhan Masykur, 2017).

Pembelajaran berbasis web merupakan kegiatan pembelajaran yang memanfaatkan media situs (website) yang bisa diakses melalui jaringan internet (Permadi, 2016). Pembelajaran berbasis web dibangun melalui beberapa prinsip yang dapat menentukan keberhasilan proses pembelajaran yaitu interaksi, ketergunaan, dan relevansi (Lukitaningrum, 2016). Media pembelajaran berbasis web merupakan alternative media pembelajaran yang memungkinkan menggabungkan berbagai macam media seperti teks, gambar, audio, video, bahkan simulasi. Media belajar berbasis web merupakan salah satu bentuk aplikasi dari system E-Learning.

E-Learning adalah media pembelajaran dengan menggunakan elektronik baik secara online maupun offline yang diaplikasikan dalam pendidikan konvesional (Adhitya, 2016). Berdasarkan Peraturan Menteri Pendidikan dan Kebudayaan Republik Indonesia No.109 tahun 2013 tentang penyelenggaraan pendidikan jarak jauh pada pendidikan tinggi yaitu pada pasal 1 nomor 4 bahwa "Pembelajaran elektronik (e-learning) adalah pembelajaran yang memanfaatkan paket informasi berbasis teknologi informasi dan komunikasi untuk kepentingan pembelajaran yang dapat diakses oleh peserta didik kapan saja dan di mana saja" (Budianto, 2018).

E-Learning juga merupakan pembelajaran milenial dan modern melalui media internet atau web yang menuntut siswa untuk mengembangkan kemampuan belajar mandiri (Lutfiana, 2019). Teknologi pembuatan system
p-ISSN : 1858-3911, e-ISSN : 2614-5405

https://journal.uniku.ac.id/index.php/ilkom

informasi berbasis website berkembang cepat serta penggunaan Bahasa PHP sebagai Bahasa pemrograman melahirkan Framework. Laravel merupakan framework yang menyediakan teknologi baru untuk memudahkan pengguna membangun aplikasi web berbasis bahasa pemrograman PHP, Laravel telah menggunakan teknologi Composer yang merupkan fitur tambahan untuk PHP (Gunawan, 2015).

Berdasarkan jurnal Budianto (2018) Laravel adalah framework PHP open source yang dibuat untuk membantu developer dalam membuat sebuah web yang sederhana, elegan, dan ekspresif daripada menggunakan bahasa pemrograman PHP biasa. Laravel mengurangi tugas-tugas umum developer pada sebagian besar proyek web seperti routing, session, dan caching. Adapun kelebihan framework Lavarel adalah sebagai berikut :

Expresif, artinya ketika seorang programmer melihat sintaks lavarel maka diharapkan akan langsung mengetahui kegunaan dari sintaks tersebut.

Sinple, Sintaks Lavarel memiliki Eloquent ORM didalamnya yang memudahkan kita dalam mengambil seluruh data hanya dengan membuat class model

Accessible, Code Developer dari Lavarel berkomitmen untuk selalu menyertakan dokumentasi yang lengkap setiap kali rilis versi terbarunya (Aminudin, 2015).

Laravel adalah kerangka PHP yang paling canggih dan elegan \& membuat proses pengembangannya sederhana. Ini memproses logika non-bisnis sendiri yang memungkinkan programmer untuk fokus pada logika bisnis suatu aplikasi (Jadhav, 2017). Laravel sendiri dibangun dengan menggunakan konsep MVC (Model-ViewController). Menurut Aditya, Putra, Pramana, Luh, \& Srinadi (2019) ,Model pada Laravel merupakan representasi 
JURNAL NUANSA INFORMATIKA

Volume 14 Nomor 1, Januari 2020

struktur data yang memiliki fungsi- fungsi yang dapat digunakan untuk mengelola basis data. View pada Laravel adalah bagian yang mengatur antarmuka website agar pengguna dapat berinteraksi dengan aplikasi yang dibuat. Controller pada Laravel merupakan bagian yang menjadi jembatan antara Model dan View dengan mengirimkan permintaan dari View dan menerima respons dari Model. Model View Controller adalah pola yang terdiri dari 3 jenis kelas yang berbeda yang setiap kelasnya memiliki tugas atau kegunaannya masing-masing (Solanki, Shah, \& Shah, 2017). Menurut Parkar, Shinde, Gadade, \& Shinde (2016) Jika diukur berdasrkan tingkat efisiensi, efisiensi pengembangan moetode desain web berdasarkan kerangka Lavarel lebih tinggi dibandingkan dengan metode desain web tradisional. Penelitianpenelitian mengenai Framework Lavarel dalam suatu system sudah banyak dilakukan.

Ruli Erinton, Ridha Muldina Negara, (2017) melakukan penelitian yang berjudul Analisis Performasi Framework Codeigniter Dan Laravel Menggunakan Web Server Apache. Penelitian tersebut bertujuan untuk menganalisis performasi antara dua framework yaitu framework CodeIgniter dan Framework Lavarel dengan menggunakan analisis pengujian load test dan pengujian stress test. Berdasarkan dari hasil pengujian didapatkan kesimpulan bahwa aplikasi web yang menggunakan framework CodeIgniter lebih baik dari sisi perfomasinya dibandingkan dengan menggunakan framework Lavarel.

Penelitian mengenai Penerapan Konsep MVC Pada Aplikasi Web Menggunakan Framework Lavarel dilakukan oleh Sy (2018), penelitian ini bertujuan untuk menganalisis masalah aplikasi berbasis web mengenai Back-end dan Front-end yang sering menyatu sehingga programmer susah untuk
p-ISSN : 1858-3911, e-ISSN : 2614-5405

https://journal.uniku.ac.id/index.php/ilkom

melakukan pengembangan system. Metode yang digunakan untuk menyelesakan solusi ini yaitu dengan menggunakan konsep MVC. Dengan konsep ini aplikasi dibagi menjadi tiga bagian yaitu Model, View dan Controller sehingga struktur aplikasi menjadi lebih jelas.

Hasil pengaplikasian konsep MVC yaitu membuat kode aplikasi menjadi lebih terstruktur. Pembagian / pemisahan aplikasi menjadi 3 bagian (Model, View dan Controller) membuat programmer lebih mudah melakukan proses pengembangan program karena setiap kode memiliki posisi masing-masing sehingga proses analisa aplikasi menjadi lebih mudah. Pemisahan ini juga memungkinkan aplikasi dikerjakan oleh orang yang berbeda, misal satu orang mengurusi logika dan yang lainya menangani tampilan aplikasi, hal ini dapat terjadi karena dalam konsep ini kode yang berhubungan dengan logika dan kode yang berhubungan dengan tampilan aplikasi terpisah.

Penelitian mengenai Framewor Lavarel juga dilakukan oleh Zuhdi, Subiyanto, \& Sukamta (2017), penelitian yang berjudul Management Information System of Laboratory Using Lavarel Framework: Case Study at Electrical Enginering of Universitas Negeri Semarang dengan tujuan pengembangan sistem informasi manajemen laboratorium yang memfasilitasi penjadwalan pekerjaan laboratorium, studi kasus di Laboratorium Teknik Elektro UniversitasNegeri Semarang. Langkah-langkah membangun sistem ini dimulai dari tahap pengumpulan data, fase desain, dan fase konstruksi. Sistem informasi ini dibangun dengan menggunakan framework laravel berbasis MVC (Model-View-Controller). Sistem ini dibuat dengan menggunakan bahasa pemrograman PHP dan database MySQL. Sistem informasi dibuat untuk memudahkan dan memfasilitasi Ketua Laboratorium, Laboratorium Lembaga Pendidikan, dan siswa dalam memantau 
JURNAL NUANSA INFORMATIKA

Volume 14 Nomor 1, Januari 2020

kegiatan laboratorium, termasuk pekerjaan laboratorium data, pemilihan data penjadwalan laboratorium, data dosen, data mata pelajaran dan data laboratorium dari Rekayasa Kelistrikan. Berdasarkan hasil pengujian, SIMLAB cukup efektif untuk diterapkan di laboratorium Teknik Elektro Universitas Negeri Semarang.

Mahmood, Ashour, Ucan, \& Bayat (2019) melakukan penelitian yang berjudul Design and Implementation of Web Based For Intermediate Online Shop with Lavarel Framework. Penelitian ini bertujuan untuk menganalisis, merangcang, dan mengimplementasikan situs web untuk membeli untuk EKomersial menggunakan pola MVC. Hasil penelitian yaitu menggunakan MVC untuk mengembangkan aplikasi lebih aman serta lebih efisien.

Persamaan antara penelitian ini dengan penelitian terdahulu yaitu menggunakan Framework Lavarel dengan konsep MVC. Perbedaannya terletak pada objek penelitian yaitu rumus matematika dengan penerapan MVC di web. Penelitian ini merupakan pengembangan penelitian sebelumnya dengan menggunakan ide peneliti.

\section{METODE PENELITIAN}

Alur metodologi yang dilakukan adalah sesusai pada Gambar 1 .

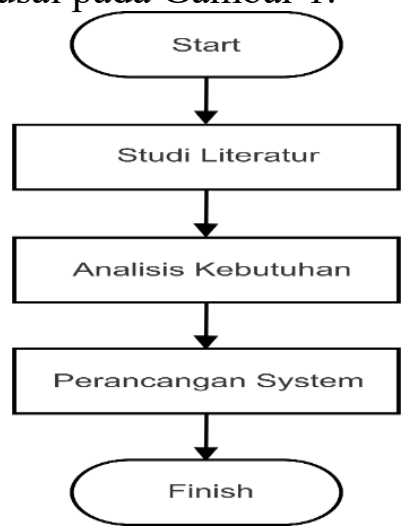

Gambar 1. Alur Perancangan

\subsection{Studi Literatur}

Penelitian ini mengambil sumber dari jurnal-jurnal serta E-book dan segala
p-ISSN : 1858-3911, e-ISSN : 2614-5405

https://journal.uniku.ac.id/index.php/ilkom

referensi yang mendukung guna kebutuhan penelitian. Sumber yang diambil adalah sumber yang berkaitan dengan Pendidikan era modern, Framework Lavarel dan konsep MVC. Review literature ini bertujuan untuk membangun konsep penelitian yang lebih kuat bersumber dari penelitian-penelitian empiris yang pernah dilakukan. Dalam penelitian ini peneliti menggunakan 20 artikel atau kajian yang saling berkaitan dengan pembelajaran elektronik berbasis web, dan framework Lareval, terdiri atas 15 jurnal dan kajian konseptual untuk memperkuat argument dan 5 artikel empiris yang dipublikasikan dalam jurnal internasional.

\subsection{Analisis Kebutuhan}

Analisis kebutuhan merupakan langkah awal yang harus dilakukan dalam kegiatan penelitian di bidang pengembangan. Pengumpulan data dalam kebutuhan penelitian dilakukan dari analisis dari berbagai jurnal. Hasil dari analisis ini akan digunakan sebagai pedoman untuk membuat suatu media pembelajaran berbasis web.

\subsection{Perancangan System}

Setelah tahap analisis kebutuhan peneliti dapat menggambarkan model sistem untuk memvalidasi persyaratan bisnis untuk kelengkapan dan konsistensi. Fase desain logis menafsirkan persyaratan bisnis ke dalam model sistem berupa diagram UML untuk menunjukan sistem independen dari solusi teknis. Peneliti menarik model sistem untuk dikelompokkan dalam model data logis, model proses logis dan model antarmuka logis yang mewakili persyaratan data dan informasi (Pengetahuan), persyaratan proses bisnis (Proses) dan persyaratan antarmuka sistem (Komunikasi).

\section{HASIL DAN PEMBAHASAN}

3.1 Layout Home

Pada Gambar 2, merupakan tampilan utama ketika membuka sistem 
JURNAL NUANSA INFORMATIKA

Volume 14 Nomor 1, Januari 2020

pembelajarannya.

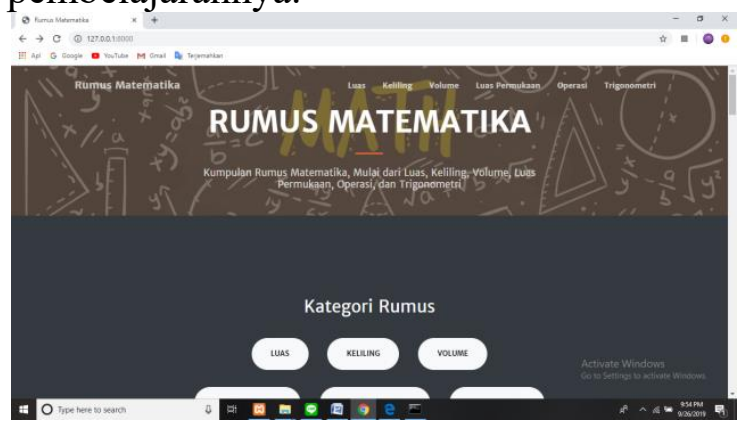

Gambar 2. Layout Home

\subsection{Layout Kategori Rumus}

Pada Gambar 3 , merupakan tampilan utama ketika membuka sistem pembelajaran pada bagian Kategori rumus.

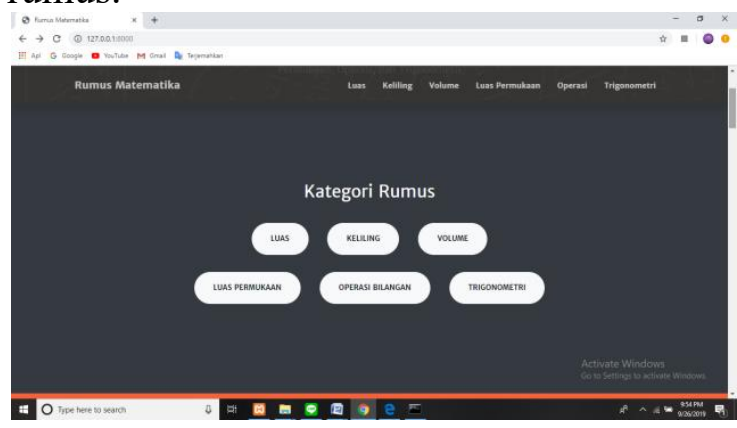

Gambar 3. Layout kategori rumus

\subsection{Layout Rumus Luas}

Pada Gambar 4 , merupakan tampilan utama ketika membuka sistem pembelajaran pada bagian rumus luas.

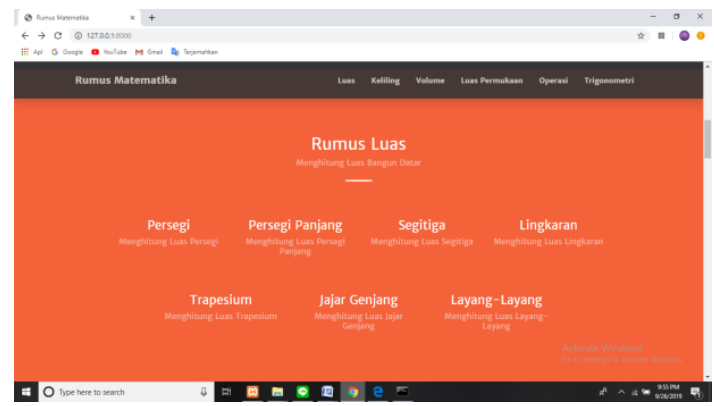

Gambar 4. Layout Rumus Luas

\subsection{Layout Rumus Keliling}

Pada Gambar 5 , merupakan tampilan utama ketika membuka sistem pembelajaran pada bagian rumus keliling.
p-ISSN : 1858-3911, e-ISSN : 2614-5405

https://journal.uniku.ac.id/index.php/ilkom

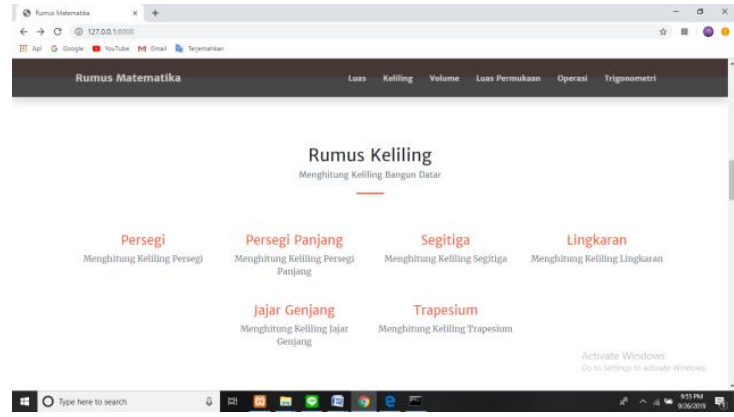

Gambar 5. Layout rumus keliling

\subsection{Layout Rumus Volume}

Pada Gambar 6 , merupakan tampilan utama ketika membuka sistem pembelajaran pada bagian rumus volume.

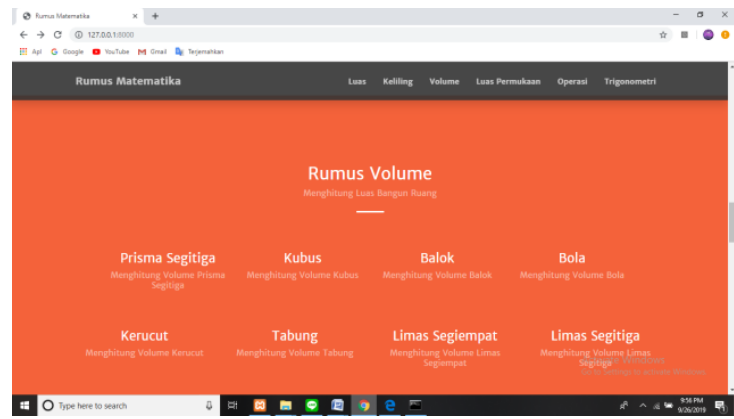

Gambar 6. Layout rumus volume

\subsection{Layout Rumus Luas Permukaan}

Pada Gambar 7 , merupakan tampilan utama ketika membuka sistem pembelajaran pada bagian rumus luas permukaan.

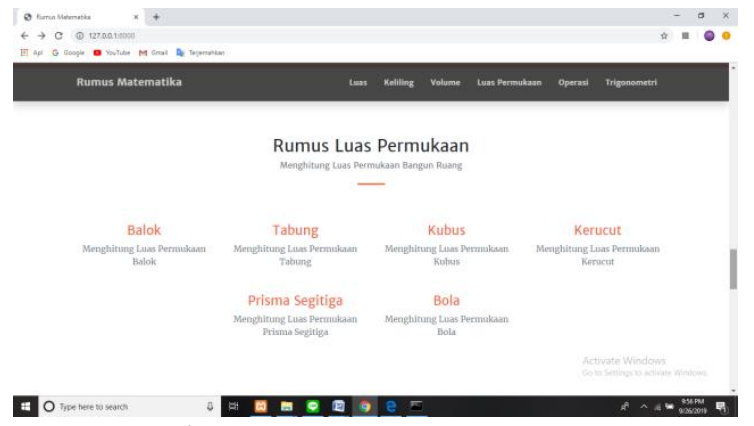

Gambar 7. Layout Rumus Luas Permukaan

\subsection{Layout Operasi Bilangan}

Pada Gambar 8 , merupakan tampilan utama ketika membuka sistem pembelajaran pada bagian operasi bilangan. 
JURNAL NUANSA INFORMATIKA

Volume 14 Nomor 1, Januari 2020

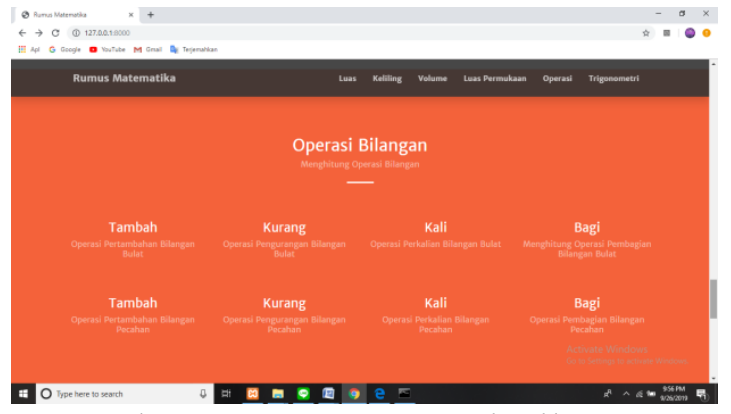

Gambar 8. Layout Operasi Bilangan

\subsection{Layout Rumus Trigonometri}

Pada Gambar 9 , merupakan tampilan utama ketika membuka sistem pembelajaran pada bagian rumus trigonometri.

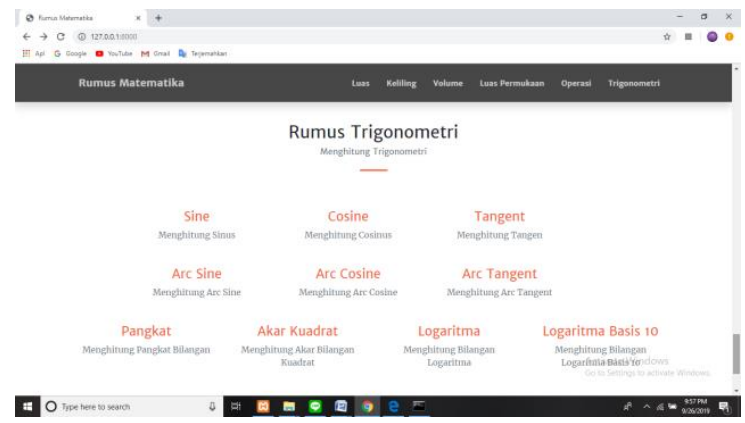

Gambar 9. Layout Rumus Trigonometri

\subsection{Layout Navbar dan Item}

Pada Gambar 10 , merupakan tampilan utama ketika membuka salah satu navbar dan item pada sistem pembelajaran.

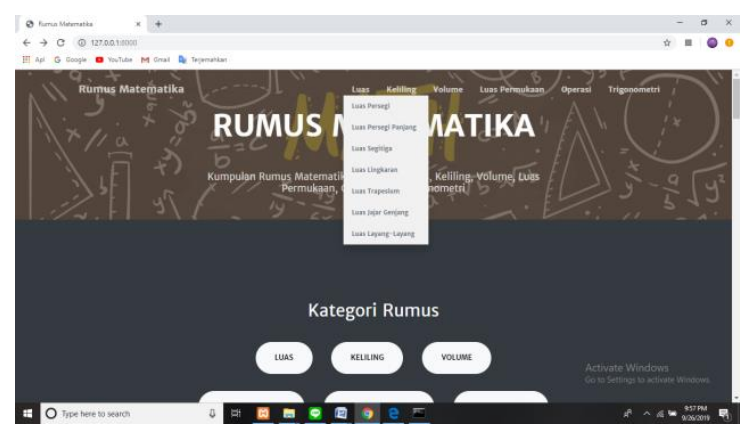

Gambar 10. Navbar dan Item

\subsection{Layout Perhitungan beserta hasil}

Pada Gambar 11 , merupakan tampilan utama ketika membuka melakukan perhitungan serta hasil yang
p-ISSN : 1858-3911, e-ISSN : 2614-5405

https://journal.uniku.ac.id/index.php/ilkom

ditampilkan pada sistem pembelajaran.

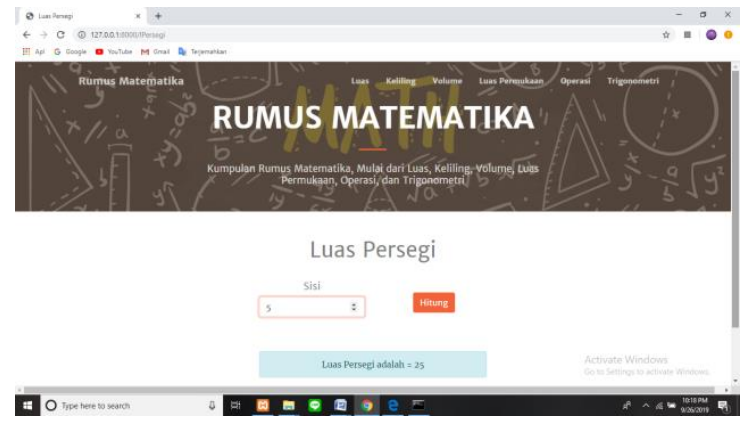

Gambar 11. Layout Perhitungan beserta hasil

Sistem Pembelajaran yang dibuat dirancang dengan menu rumus matematika dasar. Menu rumus matematika dasar ini merupakan kumpulan beberapa rumus yang dijadikan satu dalam satu sistem pembelajaran. Berdasarkan menu rumus matematika ini nantinya, diharapkan pengguna dapat lebih mudah dalam proses pembelajaran. Hal Ini sesuai dengan manfaat Sistem Pembelajaran dalam dunia pendidikan, yaitu menjadi lebih produktif, mendapatkan keunggulan dalam proses belajar, menjangkau lebih banyak pengguna khususnya para siswa - siswa sekolah dasar hingga menengah atas.

\section{KESIMPULAN}

Keterampilan berpikir, bersikap dan bertindak sebagai siswa dapat ditingkatkan melalui pembelajaran yang mengacu pada sifat pembelajaran konstruktif, interaktif dan reflektif. Belajar matematika berbasis web dengan metode Framework Lavarel dapat memudahkan siswa di era milenial untuk mengakses rumus-rumus matematika dengan mudah dan menyenangkan. Motivasi belajar siswa dapat ditungkatkan melalui media belajar yang interaktif dan inovatif.

\section{SARAN}

Saran yang diberikan setelah dilakukan penelitian ini untuk pengembangan lebih 
JURNAL NUANSA INFORMATIKA

Volume 14 Nomor 1, Januari 2020

lanjut adalah User interface yang dibangun masih tampak sederhana, sehingga perlu dibuat rancangan interface yang lebih menarik.

\section{DAFTAR PUSTAKA}

Adhitya, B. S. (2016). Pengembangan Media Pembelajaran Berbasis Web Pada Mata Kuliah Mesin.

Aditya, I. K., Putra, H., Pramana, D., Luh, N., \& Srinadi, P. (2019). Sistem Manajemen Arsip Menggunakan Framework Laravel dan Vue . Js ( Studi Kasus : BPKAD Provinsi Bali ). Sistem Dan Informatika, 13 (2), 97-104.

Aditya, P. T. (2018). Pengembangan Media Pembelajaran Matematika Berbasis Web Pada Materi Lingkaran Bagi Siswa Kelas Viii. Jurnal Matematika Statistika Dan Komputasi, 15(1), 64. https://doi.org/10.20956/jmsk.v15i1. 4425

Aminudin. (2015). Cara Efektif Belajar Framework Laravel.

Budianto, H. A. (2018). Pengembangan alat bantu penulisan doa-doa harian berbasis Latex Menggunakan Framework Lavarel.

Gunawan, R. (2015). Penerapan Framework Lavarel Pada Media Pembelajaran.

Hartono, Y. (2013). Pengembangan Media Pembelajaran Pokok Bahasan Segitiga Menggunakan Macromedia Flash. Jurnal Pendidikan, 14(2), 6272.

Hasratuddin. (2018). Membangun Karakter Melalui Pembelajaran Matematika. Matematika, 6, 130141.

Jadhav, A. (2017). IJESMR I nternational J ournal OF E ngineering $S$ ciences \& $\mathrm{M}$ anagement $\mathrm{R}$ esearch. Computer Engineering, 4(5), 47-51.

Krisdiawan, R. A. (2015). PERANCANGAN E-LEARNING
p-ISSN : 1858-3911, e-ISSN : 2614-5405

https://journal.uniku.ac.id/index.php/ilkom

DENGAN METODE

COOPERATIVE LEARNING.

NUANSA INFORMATIKA, 8(1).

Lukitaningrum, H. (2016). Pengembangan Media Pembelajaran Berbasis Web Pada Materi Basis Data di Sekolah Menengah Kejuruan Kelas XI.

Lutfiana, R. D. (2019). Pengembangan Media Pembelajaran E-Learning Pada Mata Pelajaran Komputer dan Jaringan Dasar Dengan Framework Lavarel di SMK. It-Edu, 04, 90-95.

Mahmood, M. T., Ashour, O. I., Ucan, O., \& Bayat, O. (2019). Design and Implementation of Web Based For Intermediate Online Shop with Laravel Framework. Int. Journal of Comp. Science \& Mobile Computing, 8(3), 124-133.

Ningrum, M. (2017). Pengembangan Media Pembelajaran Berbasis Web untuk Meningkatkan Kemampuan Menentukan Hubungan Antar Satuan Waktu, Antar Satuan Berat, Antar Satuan Panjang Siswa Kelas 4 SDN Burengan 2 (Vol. 01).

Parkar, V. V, Shinde, P. P., Gadade, S. C., \& Shinde, P. M. (2016). Utilization of Laravel Framework for Development of Web Based Recruitment Tool. National Conference On "Changing Technology and Rural Development," 36-41.

Permadi, A. A. (2016). Pengembangan Media Pembelajaran Interaktif Berbasis Web Dengan Pemanfaatan Video Conference Mata Pelajaran Produktif Teknik Komputer Dan Jaringan Di Sekolah Menengah Kejuruan Agustinus. 1-10.

Rubhan Masykur. (2017). Pengembangan Media Pembelajaran Matematika. Jurnal Pendidikan Matematika, Vol.8(No.2), 43-52. Retrieved from https://journal.lppmunindra.ac.id/inde X.php/jkpm/article/view/2805/2290

Ruli Erinton, Ridha Muldina Negara, D. D. S. (2017). Analisis Performasi 
JURNAL NUANSA INFORMATIKA

Volume 14 Nomor 1, Januari 2020

Framework Codeigniter Dan Laravel Menggunakan Web Server Apache. EProceedings of Engineering, 4(3), 3565-3572.

https://doi.org/10.1016/j.jcfm.2006.0 5.004

Solanki, N., Shah, D., \& Shah, A. (2017). A Survey on different Framework of PHP. International Journal of Latest Technology in Engineering, Management \& Applied Science (IJLTEMAS), VI(VI), 155-158.

Sy, H. (2018). Penerapan Konsep MVC Pada Aplikasi Web Menggunakan Framework Laravel. Sistem Informasi Dan Teknologi Informasi, $V(2), 174-183$.

Zuhdi, M. I. H., Subiyanto, S., \& Sukamta, S. (2017). Management information systems of laboratory using laravel framework:case study at electrical engineering of Universitas Negeri Semarang. Jurnal Pendidikan Vokasi, 7(2), 158. https://doi.org/10.21831/jpv.v7i2.133 $\underline{1}$
p-ISSN : 1858-3911, e-ISSN : 2614-5405

https://journal.uniku.ac.id/index.php/ilkom 